\title{
Paternally Methylated
}
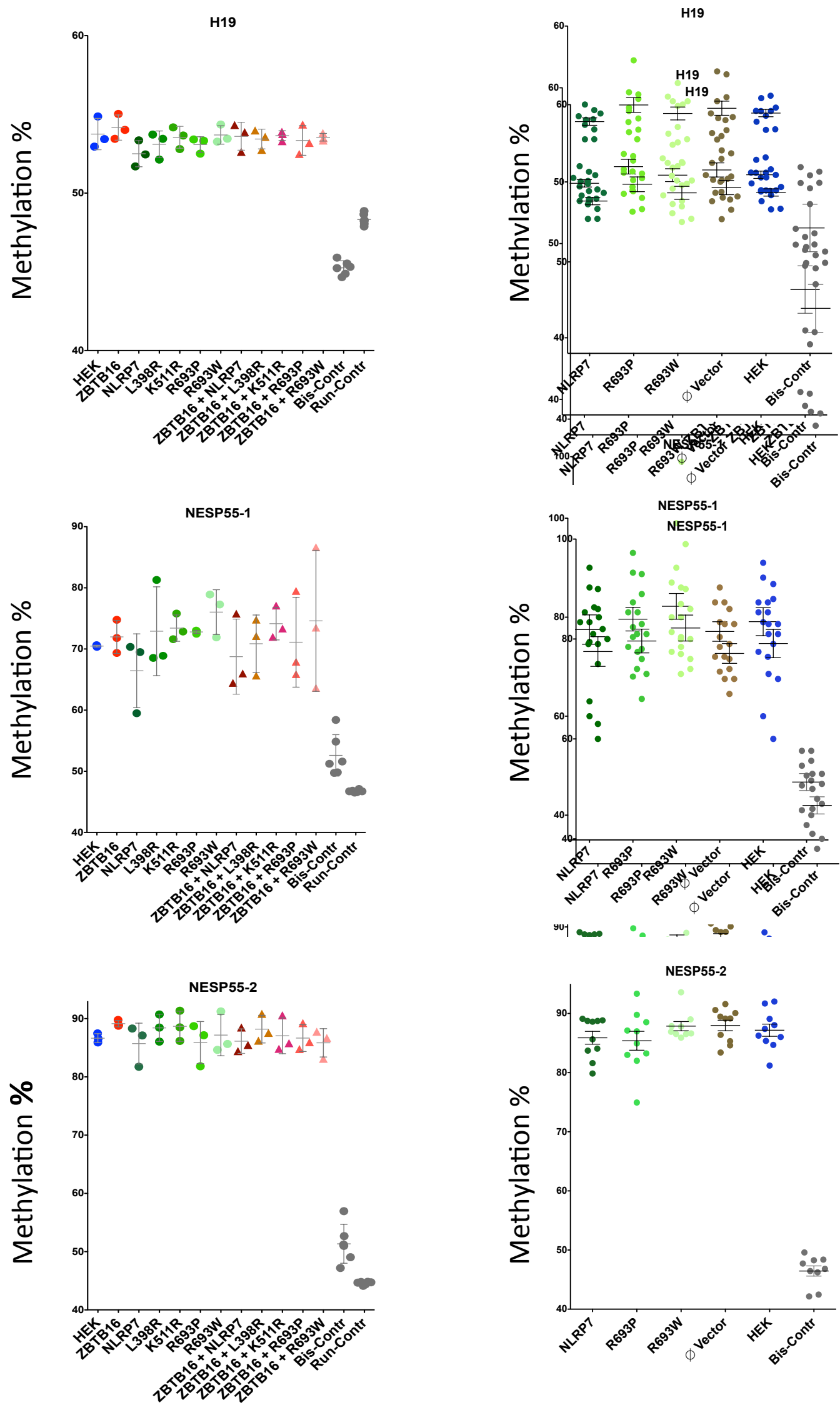